удК 338.436 .33

\title{
ЗРОСТАННЯ ЕКОНОМІЧНОЇ ЕФЕКТИВНОСТІ ЗЕРНОВИРОБНИЦТВА
}

\section{INCREASE IN THE ECONOMIC EFFICIENCY OF GRAIN PRODUCTION}

\author{
Кравчук Наталія Іванівна \\ кандидат економічних наук, доцент, \\ Поліський національний університет \\ ORCID: https://orcid.org/0000-0002-0541-8057 \\ Менчинський Олександр Олексійович \\ магістрант, \\ Поліський національний університет \\ ORCID: https://orcid.org/0000-0002-9112-5313 \\ Томчик Олександр Вікторович \\ магістрант, \\ Поліський національний університет \\ ORCID: https://orcid.org/0000-0002-3580-4346 \\ Kravchuk Nataliia, Menchynskyi Oleksandr, Tomchyk Oleksandr \\ Polissia National University
}

\begin{abstract}
Стаття присвячена дослідженню теоретичних засад та практичних рекомендацій підвищення економічної ефективності зерновиробництва. Викладено сучасний рівень зерновиробництва в Україні та Житомирській області. Здійснено оцінку впливу чинників на економічну ефективність зернової галузі, зокрема: технологічні - родючість ґрунтів, технологія обробітку ґрунту, норма висіву та внесення мінеральних добрив, строки збору урожаю, технічне забезпечення; економічні - структура виробництва, ринкова кон'юнктура, урожайність, собівартість та структура витрат виробництва, ціна реалізації. Окреслено пріоритетні напрями державного програмування, обсяги і джерела фрінансування проектних заходів, цільові очікувані результати державного регулювання зернової галузі регіону. Запропоновано організаційно-економічні напрями зростання економіки зерновиробництва в регіоні відповідно програми розвитку АПК Житомирської області до 2027 р.
\end{abstract}

Ключові слова: ефективність, сільське господарство, зерновиробництво, собівартість, рентабельність.

Статья посвящена исследованию теоретических основ и практических рекомендаций по повышению экономической эсроективности производства зерна. Изложен современный уровень производства зерновых в Украине и Житомирской области. Определена роль зерновой отрасли в экономике региона. Осуществлена оценка влияния факторов на экономическую эфрфективность зерновой отрасли, в частности: технологические - плодородие почв, технология обработки почвы, норма высева и внесения минеральных удобрений, сроки сбора урожая, техническое обеспечение; экономические - структура производства, рыночная конъюнктура, урожайность, себестоимость и структура издержек производства, цена реализации. Намечены приоритетные направления государственного программирования, объемы и источники оринансирования проектных мероприятий, целевые ожидаемые результаты государственного регулирования зерновой отрасли региона. Предложены организационно-экономические направления роста экономики производства зерна в регионе в соответствии с программой развития АПК Житомирской области до 2027 г.

Ключевые слова: эфффективность, сельское хозяйство, производство зерна, себестоимость, рентабельность.

The article is devoted to the study of theoretical foundations and practical recommendations to improve the economic efficiency of grain production. The research methodology is based on the use of general scientific and special methods. In particular, analysis and synthesis, scientific abstraction, logical to make generalizations, conclusions and recommendations. Used such statistical techniques as series of dynamics in ranking the regions of Ukraine on sown areas and volumes of grain production, averages to calculate the weighted average yield, cost and profitability. The method of comparison is used to find the deviation of actual indicators from the basic ones. Graphical 
and computationally-constructive method is used to clearly reflect the main results of the study and their economic justification. The program-target method was used in the establishment of the main objectives of the development of grain farming in the region until 2027. The main results of the study were the following provisions. The modern level of grain production in Ukraine and Zhytomyr region, in particular, was estimated. The influence of factors on the economic efficiency of grain industry was estimated, namely: technical and technological (technology of growing products and technical equipment of the industry), economic (structure of production, market conjuncture, yield, cost price and structure of production costs, selling price). The structural and logical scheme of the program of Zhytomyr Region agroindustrial complex development for the period up to 2027 is built and the place of grain farming in it is determined. The main program priorities, volumes and sources of their financing in the region are identified. It is established that rye and buckwheat are priority cereal crops that require state regulation and incentives. Organizational and economic directions of growth of the economy of grain production in the region according to the program of development of the agroindustrial complex of Zhytomyr region till 2027 are suggested. Target benchmarks in the grain product subcomplex, which determine the practical value of the research conducted, were identified. The growth rates of grain production and products of grain processing are determined. According to the planned measures it is expected to increase the gross harvest of rye by $37.6 \%$ and buckwheat by $67.8 \%$ by the end of the program period. The combination of the outlined measures will contribute to the growth of food security, which is realized in an increase in the indicator of grain supply to $2678 \mathrm{~kg}$ per capita in the Zhytomyr region.

Keywords: effectiveness, agriculture, grain production, prime cost, profitability.

Постановка проблеми. Обмеженість ресурсів планети та зростання чисельності населення загрожує продовольчій безпеці та зумовлює потребу наукового пошуку шляхів есрективного використання наявного ресурсного потенціалу, раціонального розміщення продуктивних сил та фрормування гармонійних виробничих відносин між природою та людиною. Вирішити глобальні проблеми дозволяє успішна стратегія розвитку господарських комплексів, що основана на ефрективності та ощадливості. У міжнародному поділі праці Україна займає вагоме місце як зернова країна, $€$ експортно орієнтованою та суттєво впливає на продовольчу безпеку Європи. Зернове господарство визначає спеціалізацію кожного регіону нашої країни, а тому $€$ стратегічною галуззю національної економіки. Відтак, розробка шляхів зростання економічної ефрективності виробництва зерна в Україні $€$ актуальним завданням науковців і практиків, що обумовило вибір теми дослідження.

Аналіз останніх досліджень і публікацій. Класиками української школи ефрективності аграрного виробництва $€$ Андрійчук В.Г. [1], Саблук П.Т. [2], Нелеп В.М. [3], Черевко Г.В. [4] та інші, які досліджують організаційно-економічні аспекти зростання ефрективності сільськогосподарського виробництва, у тому числі і зернового господарства. Наразі, досить вагомими $€$ останні надбання та дослідження. Досить вичерпну класифрікацію економічної ефрективності за різними ознаками наводять науковці Череп А.В., Стрілець Є.М. [5]. Ринковий, доходний і витратний методи оцінки економічної ефрективності, переваги і недоліки їх застосування пропонують Погребняк А.Ю. та Лінник I.М. [6]. При здійсненні оцінки економічної ефрек- тивності виробництва певного виду продукції у сільському господарстві Драгоєва О.В., Морозович А.В. [7] та Зигрій О.В. [8] пропонують користуватися системою натуральних та вартісних показників, що поділяються на узагальнюючі показники; есрективності використання трудових і матеріальних ресурсів; показники якості продукції; урожайність.

Виділення невирішених раніше частин загальної проблеми. 3 огляду на зазначене, доцільним вбачається використати традиційну методику оцінки економічної есрективності у галузі зерновиробництва та доповнити наукові здобутки вітчизняних науковців практичними рекомендаціями її підвищення в умовах Північно-Західного Полісся.

Формулювання цілей статті. Метою дослідження $€$ розробка теоретико-методологічних положень та обґрунтування науковопрактичних рекомендацій щодо підвищення ефективності виробництва зернових культур.

Об'єктом дослідження $є$ процес зростання економічної есрективності виробництва зернових культур у підприємствах Житомирської області.

При дослідженні теоретичних засад категорії, оцінці досягнутих показників розвитку галузі та здійсненні теоретичних узагальнень і висновків використано загальнонаукові методи аналізу і синтезу, індукції та дедукції, абстрактно-логічний. Прийоми статистичних методів такі, як табличний, графрічний, ранжування, групування, побудова рядів динаміки, застосовано в аналітичній частині роботи для детального глибокого розуміння проблеми. Прогнозування і програмування імплементовано при розробці та обґрунтуванні пропозицій підвищення економічної ефрективності виробництва зернових. 
Виклад основного матеріалу. Зернова галузь є стратегічно важливою для економіки України, оскільки становить основу продовольчої безпеки. В цілому зерновий комплекс може складатися від 3 до 22 суміжних виробництв: зернове, хлібобулочне, борошномельно-круп'яне, спиртове, кондитерське, комбікормове тощо [9]. Окрім того, обслуговують основне виробництво елеватори, приймальні бази, біржі, оптові ринки, аукціони, банки, кредитні установи, страхові компанії, транспортна система, інорормаційно-аналітичні та контролюючі організації, Аграрний фонд та інші суб'єкти виробничої, ринкової, фрінансово-кредитної та інфрормаційно-консультативної інорраструктури.

Зернове господарство $€$ однією $з$ галузей спеціалізації усіх регіонів України. За даними Державної служби статистики [10] провідні місця за обсягами виробництва займають Одеська - 9,9\%, Запорізька - 8,1\%, Харківська - 7,8\%, Дніпропетровська - 7,6\% і Миколаївська - 7,4\% області (табл. 1).

Всього в Україні станом на 01.10.2021 р. зібрано 43,8 млн т зернових з площі 10,1 млн га. Для порівняння, у середньому посівна площа у період 1990-2000 рр. становила 14 млн га, у 2000-2020 рр. - 15 млн га. Середня урожайність в Україні становить 43,2 ц/га.

Житомирська область займає 18-те місце у рейтингу урожаю зернових та має наближену до середньої по Україні урожайність 43,1 ц/га. За останні 5 років виробництво усіх культур зростає. Так, валові збори зернових збільшилися на $27,8 \%$ у 2020 р. порівняно 3 2014 р.; цукрових буряків - на 52,5\%, насіння соняшника - на 94\%, картоплі - на $60 \%$, овочевих - на 67\% (табл. 2).

Головним чином це відбувається за рахунок зростання урожайності. За даними Головного управління статистики у Житомирській області урожайність зернових культур у всіх категоріях господарств у поточному порівняно з попереднім роком зросла на 13,2\% [12], у тому числі урожайність пшениці - на 15,3\%, ячменю - на 7,1\%, кукурудзи на зерно - на 8,3\%.

Важливим економічним показником ефективності виробництва $€$ витрати з розрахунку на 1 ц виробленої продукції або 1 га посівної площі. Виробнича собівартість 1 ц зернових у 2020 р. в цілому в галузі в Україні становила 355,6 грн/ц (табл. 3).

У Житомирській області цей показник нижчий на 7,3 грн. У розрізі видів зернових культур лише собівартість кукурудзи на зерно $€$ нижчою на 5,7 грн від середнього значення по Україні. Решта продукції - пшениця, ячмінь, жито, овес, гречка, просо - перевищує загальнодержавний рівень.

Як зазначає керівник фермерського господарства «Таранчук А.П.», собівартість виробництва пшениці в його господарстві зросла до 20 тис. грн/га, у тому числі найбільше відрахувань складають податки та розрахунки із власниками земельних паїв (близько 8 тис. грн/га), витрати на добрива та захисні

Рейтинг збору урожаю зернових в господарствах усіх категорій в регіонах України станом на 01.09.2021 p.

\begin{tabular}{|c|c|c|c|c|c|c|c|}
\hline \multirow{2}{*}{\multicolumn{2}{|c|}{ Perion }} & \multicolumn{2}{|c|}{ Площа зібрана } & \multicolumn{2}{|c|}{ Обсяг виробництва } & \multicolumn{2}{|c|}{ Урожайність } \\
\hline & & тис. га & $\%$ & тис. 4 & $\%$ & ц/га & $+1-$ \\
\hline & Україна & 10149,9 & 100,0 & 438043,8 & 100 & 43,2 & \\
\hline 1 & Одеська & 1076,6 & 10,6 & 43514,3 & 9,9 & 40,4 & $-2,8$ \\
\hline 2 & Запорізька & 973,9 & 9,6 & 35610,7 & 8,1 & 36,6 & $-6,6$ \\
\hline 3 & Харківська & 756,8 & 7,5 & 34269,6 & 7,8 & 45,3 & 2,1 \\
\hline 4 & Дніпропетровська & 833,5 & 8,2 & 33427,7 & 7,6 & 40,1 & $-3,1$ \\
\hline 5 & Миколаївська & 812,3 & 8,0 & 32252,9 & 7,4 & 39,7 & $-3,5$ \\
\hline & & & & & & & \\
\hline 18 & Житомирська & 242,2 & 2,4 & 10432,1 & 2,4 & 43,1 & $-0,1$ \\
\hline$\cdots$ & & & & & & & \\
\hline 20 & Волинська & 262 & 2,6 & 10244,8 & 2,3 & 39,1 & $-4,1$ \\
\hline 21 & Рівненська & 204,5 & 2,0 & 8488,8 & 1,9 & 41,5 & $-1,7$ \\
\hline 22 & Іван-Франківська & 80,8 & 0,8 & 3773,3 & 0,9 & 46,6 & 3,4 \\
\hline 23 & Чернівецька & 54,4 & 0,5 & 2555,9 & 0,6 & 46,9 & 3,7 \\
\hline 24 & Закарпатська & 26,4 & 0,3 & 873,5 & 0,2 & 33 & $-10,2$ \\
\hline
\end{tabular}

Джерело: побудовано автором за даними Державної служби статистики [10] 
Таблиця 2

Виробництво основних сільськогосподарських культур

підприємствами Житомирської області на 1 жовтня відповідного року, тис. ц

\begin{tabular}{|c|c|c|c|c|c|}
\hline Рік & $\begin{array}{c}\text { Зернові та } \\
\text { зернобобові }\end{array}$ & $\begin{array}{c}\text { Буряк } \\
\text { цукровий }\end{array}$ & $\begin{array}{c}\text { Насіння } \\
\text { соняшника }\end{array}$ & Картопля & $\begin{array}{c}\text { Культури } \\
\text { овочеві }\end{array}$ \\
\hline 2015 & 8766,9 & 1307,0 & 493,1 & 11670,2 & 2233,5 \\
\hline 2016 & 11193,2 & 2219,1 & 1444,5 & 12975,9 & 2601,8 \\
\hline 2017 & 10411,9 & 2192,6 & 1107,8 & 16418,0 & 2974,8 \\
\hline 2018 & 10926,4 & 2188,2 & 1953,5 & 18564,7 & 2900,9 \\
\hline 2019 & 12320,9 & 1791,5 & 2114,6 & 15785,8 & 3023,2 \\
\hline 2020 & 15073,0 & 4048,8 & 3096,2 & 17696,0 & 4025,6 \\
\hline 2021 & 11200,9 & 1980,2 & 955,1 & 18627,4 & 3720,1 \\
\hline 2021 у \% до 2015 & 127,8 & 152,5 & 194,0 & 159,6 & 166,6 \\
\hline
\end{tabular}

Джерело: побудовано за даними Головного управління статистики

у Житомирській області [11]

Таблиця 3

Виробнича собівартість зернових культур

в сільськогосподарських підприємствах у 2020 р., грн/ц

\begin{tabular}{|l|c|c|c|}
\hline Найменування продукції & Україна & $\begin{array}{c}\text { Житомирська } \\
\text { область }\end{array}$ & $\begin{array}{c}\text { Відхилення } \\
\text { від середнього } \\
\text { по Україні, +l- }\end{array}$ \\
\hline Зернові та зернобобові -усього, у т.ч.: & 355,6 & 348,3 & $-7,3$ \\
\hline пшениця & 371,2 & 374,0 & 2,8 \\
\hline кукурудза на зерно & 334,8 & 329,1 & $-5,7$ \\
\hline ячмінь & 370,1 & 373,6 & 3,5 \\
\hline жито & 359,8 & 410,5 & 50,2 \\
\hline овес & 343,7 & 359,9 & 16,2 \\
\hline гречка & 879,4 & 1139,7 & 260,3 \\
\hline просо & 585,9 & 846,4 & 260,5 \\
\hline культури зернобобові сушені & 616,6 & 906,5 & 289,9 \\
\hline
\end{tabular}

Джерело: побудовано за даними Державна служба статистики України.

http://www.ukrstat.gov.ua/ [13]

препарати (близько 7 тис. грн/га) та інші непередбачувані обставини -4-5 тис. грн/га [14].

За даними статистичної служби України у структурі собівартості зернових традиційно переважають матеріальні витрати - 50\% в цілому в Україні, так і в Житомирській області. 3 них найбільша питома вага доводиться на мінеральні добрива - 17,1\% та насіння 10,9\% (табл. 4).

За результатами розрахунків експертів аграрної галузі у 2021 р. загальні витрати на 1 га вирощування пшениці озимої становлять 22 тис. грн. Відтак, «...за середньої врожайності у 6 ц/га собівартість 1 т продукції дорівнюватиме 3,6 тис. грн, за ціни реалізації пшениці 7 тис. грн/т, прибуток 31 га становитиме 20 тис. грн, що забезпечить рентабельність понад 90\%», - підкреслив Олексій Маслак [15]. Статистичні дані свідчать, що рівень рентабельності зерновиробництва $€$ недо- статнім для процесів розширеного відтворення галузі - у середньому в Україні 23,8\% у 2020 р. (табл. 5).

У розрізі зернових культур найвищий рівень рентабельності виробництва гречки - 44,9\% та кукурудзи на зерно - 29,1\%. В Житомирській області даний показник теж є позитивним, але найбільш прибутковим $€$ виробництво овса $26,6 \%$, гречки - 25,3\% та кукурудзи на зерно $23,7 \%$. Водночас динаміка головного показника ефективності виробництва в Житомирській області окремих зернових культур $€$ негативною. Так, порівняно з 2017 р. у 2020 р. знизилася рентабельність виробництва проса і ячменю на $13,4 \%$, пшениці на $10,0 \%$, гречки на $7,4 \%$. Отже, виникає необхідність поглибленого дослідження проблем розвитку галузі в Житомирській області та розробки рекомендацій щодо їх усунення.

$\mathrm{Ha}$ ефрективність виробництва зернових впливає багато фракторів, головними 
Таблиця 4

Структура виробничої собівартості зернових та зернобобових у 2020 р.

\begin{tabular}{|c|c|c|c|c|c|}
\hline \multirow{2}{*}{\multicolumn{2}{|c|}{ Стаття витрат }} & \multicolumn{2}{|c|}{ Україна } & \multicolumn{2}{|c|}{ Житомирська обл } \\
\hline & & млн грн & $\%$ & млн грн & $\%$ \\
\hline \multicolumn{2}{|c|}{ Витрати, усього } & 144500,5 & 100,0 & 5688,47 & 100 \\
\hline \multicolumn{2}{|c|}{ Прямі матеріальні витрати - усього } & 72737,89 & 50,3 & 2874,46 & 50,5 \\
\hline \multirow{4}{*}{ У т. } & насіння та посадковий матеріал & 15109,70 & 10,5 & 621,97 & 10,9 \\
\hline & мінеральні добрива & 26308,19 & 18,2 & 974,74 & 17,1 \\
\hline & пальне і мастильні матеріали & 11736,44 & 8,1 & 511,49 & 9,0 \\
\hline & решта матеріальних витрат & 1583,55 & 13,5 & 766,25 & 13,5 \\
\hline \multicolumn{2}{|c|}{ Прямі витрати на оплату праці } & 8997,17 & 6,3 & 276,94 & 4,9 \\
\hline \multicolumn{2}{|c|}{$\begin{array}{l}\text { Інші прямі витрати та загальновиробничі } \\
\text { витрати, усього }\end{array}$} & 62765,50 & 43,4 & 2537,06 & 44,6 \\
\hline \multirow{4}{*}{ у т.ч. } & відрахування на соціальні заходи & 1975,82 & 1,4 & 57,52 & 1,0 \\
\hline & амортизація & 13035,87 & 9,0 & 290,94 & 5,1 \\
\hline & оплата послуг сторонніх організацій & 12766,14 & 8,8 & 592,3 & 10,4 \\
\hline & $\begin{array}{l}\text { решта інших прямих та } \\
\text { загальновиробничих витрат }\end{array}$ & 34987,64 & 24,2 & 1596,26 & 28,1 \\
\hline
\end{tabular}

Джерело: побудовано за даними [13]

Рівень рентабельності виробництва зернових у 2020 р., \%

\begin{tabular}{|l|c|c|c|c|c|c|c|}
\hline \multirow{2}{*}{ Найменування продукції } & $\mathbf{2 0 1 7}$ р. & $\mathbf{2 0 1 8}$ р. & $\mathbf{2 0 1 9}$ р. & \multicolumn{2}{|c|}{$\mathbf{2 0 2 0}$ р. } & 2020 p. до \\
\cline { 2 - 6 } & \multicolumn{5}{|c|}{ Житомирська область } & Україна & 2017 p. , +l- \\
\hline Зернові та зернобобові, у т.ч.: & 24,5 & 23,1 & 27,0 & 20,2 & 23,8 & $-4,3$ \\
\hline пшениця & 26,8 & 24,6 & 18,7 & 16,8 & 23,6 & $-10,0$ \\
\hline кукурудза на зерно & 23,7 & 27,2 & 27,9 & 23,7 & 29,1 & 0 \\
\hline ячмінь & 24,0 & 25,6 & 21,4 & 10,6 & 14,4 & $-13,4$ \\
\hline жито & 20,2 & $-2,2$ & 20,8 & 23,1 & 27,1 & $+2,9$ \\
\hline овес & 21,2 & 10,3 & 19,2 & 26,6 & 22,5 & $+5,4$ \\
\hline гречка & 32,7 & $-17,2$ & 40,9 & 25,3 & 44,9 & $-7,4$ \\
\hline просо & 24,5 & 34,7 & 7,6 & 11,1 & 15,7 & $-13,4$ \\
\hline культури зернобобові сушені & 22,4 & $-5,4$ & 15,0 & 29,8 & 8,5 & $+7,4$ \\
\hline
\end{tabular}

Джерело: побудовано за даними [13]

серед яких на думку аграріїв, слід вважати наступні. По-перше, це оптимальна структура виробництва зерна, що відповідає ринковій кон'юнктурі. Практикою перевірено, що у структурі зернового клину провідні позиції посідають дві культури - озима пшениця й кукурудза - 40,9 та 29,9\% відповідно [16]. По-друге, це врожайність зернових, зростання якої сприяє зниженню собівартості одиниці продукції, збільшенню виручки від реалізації і прибутку з розрахунку на 1 га зібраної площі. По-третє, есрективність виробництва значною мірою залежить від технології вирощування: технології обробітку ґрунту, норм висіву та внесення мінеральних добрив, оптимальні строки жнив та сучасна техніка.

Природна родючість ґрунтів Полісся характеризується як низька, що не дає можливості одер- жувати високі врожаї сільськогосподарських культур без застосування ефективної технології внесення мінеральних добрив, що визначається трьома основними чинниками: забезпеченість ґрунту вологою, рівень його родючості, вид культури [17]. За даними Головного управління статистики у Житомирській області [18] під урожай зернових і зернобобових 2020 р. всього у фрізичній масі внесено 119,4 тис. т. У тому числі, 34 тис. т азотних добрив, 0,5 фоссрорних та 1,8 калійних. 3 розрахунку на 1 га посівів в цілому було внесено 160 кг.

На урожайність зернових впливає дотримання сівозмін. Так, за дослідженнями Інституту сільського господарства Карпатського регіону у Поліській зоні на дерново-підзолистих супіщаних ґрунтах добрі врожаї пшениці забезпечує розміщення її після люпину на 
корм і зелене добриво, картоплі ранніх сортів, льону та конюшини [19].

Захист посіві зернових є одним з важливих елементів технології вирощування зернових культур. За даними Головного управління статистики в Житомирській області у 2020 р. було оброблено 84,4\% посівної площі, у т.ч. пшениці 86,0\% та кукурудзи на зерно 88,4\% [20]. Обсяг внесених пестицидів становив 1,4 кг на 1 га обробленої площі.

Дослідження Інституту сільського господарства Західного Полісся доводять, що дотримання рекомендованого комплексу технологічних заходів, який включає поєднання таких фракторів, як сівозміна, вапнування і удобрення дозволяє підвищити продуктивність дерново-підзолистих ґрунтів до 5,7 т зернових одиниць 31 га сівозмінної площі, або в 2,5-3 рази порівняно з природним рівнем та $€$ економічно окупним [21].

На думку вчених, найдоступнішим способом підвищення врожайності сільськогосподарських культур на 15-20\% є запровадження високопродуктивних сортів і гібридів [21]. За результатами опитування APK-inform.com, 639 сільгоспвиробників у минулому році використовували 223 сорти озимої пшениці, на 15 з яких припадає 52\% всіх посівних площ [22]. Розглядаючи ТОП-15 сортів вітчизняної та іноземної селекції, слід зазначити, що найвисоковрожайнішими сортами пшениці у Житомирському Поліссі, що мають міцну генетику, є Поліська-90, та розроблені селекціонерами ННЦ «Інститут землеробства HAAН» на її основі нові сорти пшениці озимої м'якої - Столична, Артеміда, Бенефріс, Аналог і Краєвид [23].

Дослідження Інституту зернових культур НАAН України доводять вплив технології збирання урожаю на продуктивність та собівартість зернових: в перші 5-7 днів після дозрівання урожайність озимої пшениці не знижується; у наступні дні спостерігається зворотній процес: збирання через 15 днів після настання повної стиглості призводить до втрат 5-7\% зерна з га, а через 20 - від 11,2 до 13,5\% [24]. Дослідники стверджують, що «при затягуванні строків збирання до 15 днів лише через зростання собівартості зерна за ціни 4700 грн/т виробник недоотримає 528-704 грн прибутку в розрахунку на 1 га посіву» [24]. На жаль, дані статистики свідчать про зростання термінів збирання урожаю, що призводить до втрат 16,5-17,0\% зерна.

Серед економічних фракторів прибутковості виробництва зернових вагомого значення набуває ціна реалізації продукції, що впливає на виручку від реалізації та покриває витрати виробництва. У динаміці за останні 9 років починаючи 32010 р. ціна зростає 31200 грн за тону до 4300 грн за тону у 2018 р. (рис. 1).

У 2021 р. ціна реалізації зернових в Житомирській області становила 6438,9 грн/т. У січні-серпні 2021 р. сільськогосподарськими

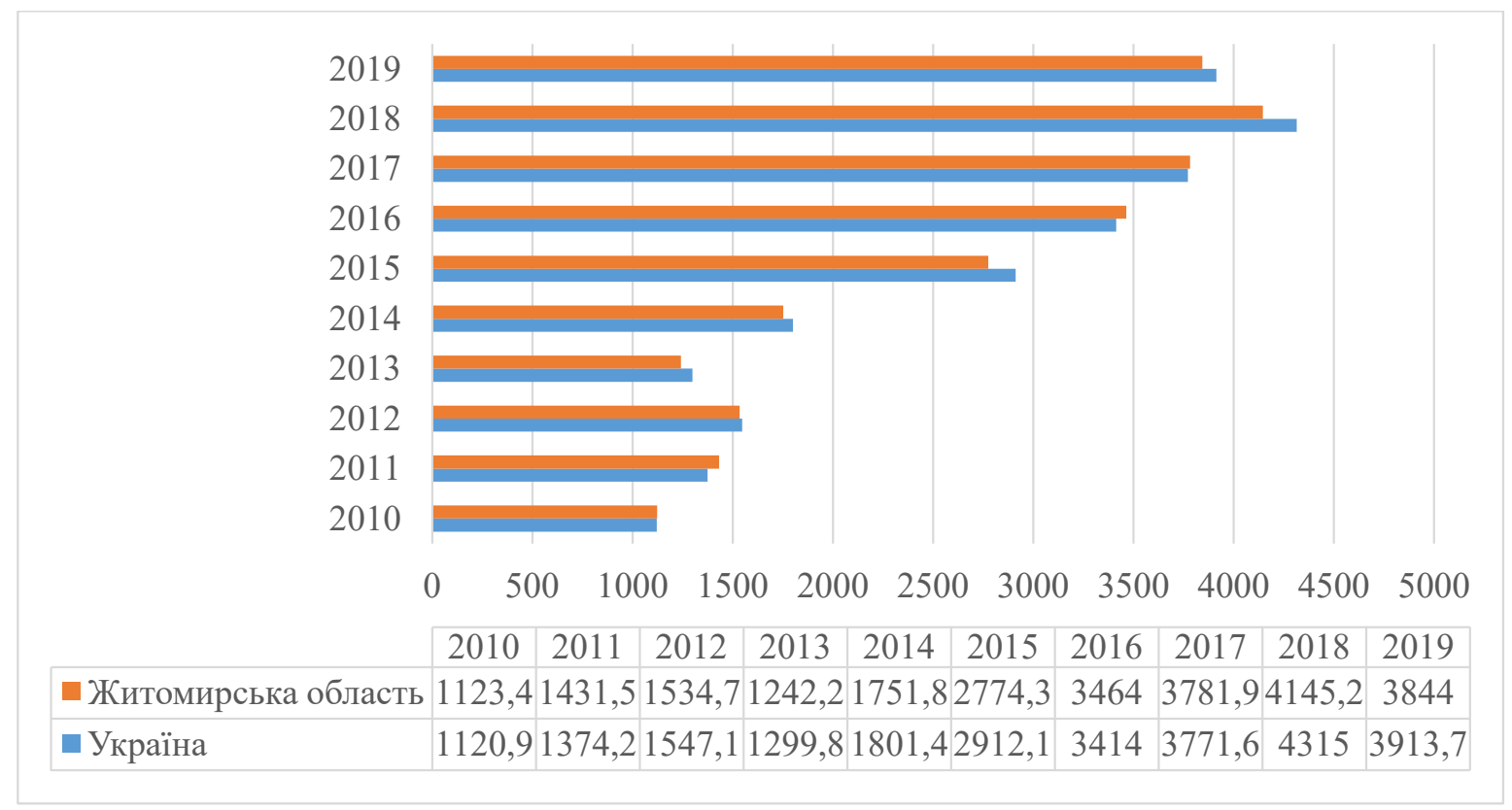

Рис. 1. Середні ціни реалізації зернових та зернобобових, грн/т (без ПдВ, дотацій, транспортних, експедиційних та накладних витрат) Джерело: побудовано за даними Державної служби статистики України [25] 
Надходження зернових культур на підприємства, що займаються їх зберіганням і переробкою, у січні-вересні 2021 р.

\begin{tabular}{|l|c|c|c|c|c|}
\hline \multirow{2}{*}{ Культура } & \multicolumn{2}{c|}{$\begin{array}{c}\text { Наявність на кінець } \\
\text { звітного періоду }\end{array}$} & $\begin{array}{c}\text { Куплено } \\
\text { 3 поч. року }\end{array}$ & \multicolumn{2}{c|}{$\begin{array}{c}\text { Середня ціна купівлі } \\
\text { 3 початк року }\end{array}$} \\
\cline { 2 - 6 } & $\mathbf{T}$ & $\mathbf{y}$ \% 2020 p. & $\mathbf{T}$ & грн/т & у \% 2020 p. \\
\hline Зернові та зернобобові, 3 них: & 6732628 & 158,8 & 5586545 & 6491,4 & 139,4 \\
\hline пшениця & 4932532 & 188,7 & 3153139 & 6462,0 & 132,4 \\
\hline 3 неї тверда & 8448 & 249,4 & 8006 & 7908,0 & 126,6 \\
\hline крім твердої & 4924084 & 188,7 & 3145133 & 6458,3 & 132,4 \\
\hline 3 неї 1 класу & 2273 & 52,7 & $\mathrm{~K}$ & $\mathrm{~K}$ & $\mathrm{~K}$ \\
\hline 2 класу & 1179392 & 142,5 & $\mathrm{~K}$ & $\mathrm{~K}$ & $\mathrm{~K}$ \\
\hline 3 класу & 2147461 & 183,6 & 1363995 & 6471,6 & 132,6 \\
\hline 4 класу & 1528320 & 279,3 & 790338 & 6215,5 & 132,7 \\
\hline
\end{tabular}

Джерело: державна служба статистики України

підприємствами було експортовано зернових на суму 71,3 млн дол. США, що становить $13,3 \%$ у структурі грошових надходжень [26]. Порівняно 3 аналогічним періодом 2020 р. ціна зросла на 39,4\% у середньому (табл. 6).

Найбільше реалізується пшениці - 70\% від усього обсягу. 3 неї м'якої пшениці реалізовано найбільше, зокрема 2-го, 3-го і 4-го класу.

Фактичні операції купівлі-продажу зерна здійснюють відповідні елементи ринкової інфрраструктури. У ТОП-5 вантажовідправників українського зерна в 2019/20 МР увійшли: «Кернел»- 7,98 млн т зерна, з часткою на ринку 13,29\%; COFCO Agri Ukraine - 5,03 млн т, або 8,37\%; «НІБУЛОН -4,98 млн т, або 8,28\%; «Каргілл» - 4,39 млн, або 7,31\%; «Луї Дрейсрус Компані Україна» - 4,13 млн т, або 6,87\% [27].

В умовах нестійкого соціально-економічного і політичного середовища фрункціонування аграрного бізнесу важливого значення набуває державне регулювання пріоритетних та стратегічно важливих галузей економіки. Одним із способів державного впливу та управління з метою підтримки та сприяння розвитку господарюючих суб'єктів є державне прогнозування та програмування. Зокрема, в

Мета програми - стабільний динамічний розвиток виробництва продукції сільського господарства шляхом створення умов через механізм підтримки виробників, у тому числі малих суб'єктів господарювання та господарств населення

Нормативно-правова основа реалізації:

- Концепція Державної цільової програми розвитку аграрного сектору економіки на період до 2022 р. (розпорядженням КМУ від 30 грудня 2015 р. № 1437-p);

- Стратегія розвитку Житомирської області на період до 2027 р. (рішення обласної ради від 18.12.2019 № 1722);

- Державна стратегія регіонального розвитку на 2021-2027 рр. (постанова КМУ від 05.08.2020 № 695)

Очікування: зростанні темпів виробництва валової продукції сільського господарства протягом 2021-2027 років, щороку не менше як на $0,3 \%$.

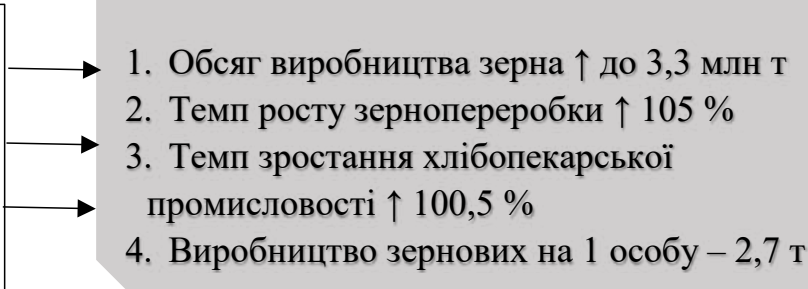

Рис. 2. Структура програмування і прогнозування розвитку АПК Житомирської області на період 2021-2027 рр. та місце в ній зернового господарства 
Житомирській області розроблена Програма розвитку агропромислового комплексу на період 2021-2027 рр. (рис. 2) з загальним обсягом фрінансових ресурсів для їі реалізації 14955,47 млн грн, у т.ч. бюджетних 2009,57 млн грн [28].

В результаті реалізації програми очікуються щорічний темп зростання виробництва валової продукції сільського господарства щонайменше 0,3\%. Загальний обсяг ресурсного забезпечення реалізації Програми розвитку АПК Житомирської області становить 15 млрд грн (табл. 7). Основними джерелами фрінансування стануть: державний та обласний бюджети, бюджети ОТГ, а також небюджетні кошти. Питома вага бюджетних коштів у середньому щороку становитиме 13,4\%. Головний акцент робиться на небюджетні кошти, зокрема приватні інвестиції, власний капітал підприємств та іноземні інвестиції.
У Програмі чільне місце відводиться зерновиробництву. За базовий обрано 2020 р., темпи приросту розраховані на наступні п'ять років, починаючи з 2021 р. відносно попереднього. У цілому, у загальних витратах на фрінансування програми у напряму зростання обсягів виробництва продукції рослинництва на зернове господарство відведено 76,6\% витрат (табл. 8).

За рахунок ряду заходів, передбачених програмою, очікується зростання обсягів виробництва зерна з 2465 тис. т у 2020 р. до 3300 тис. т у 2027 р. Значної уваги в зерновій галузі Житомирської області приділяється виробництву жита і гречки. Зокрема, планується підвищити валові збори жита на 37,6\%, гречки - на 67,8\% у 2027 р. порівняно з 2020 р.

Окрім того, згідно програми розвитку прогнозується зростання обсягів зернопереробки. Темп зростання зернопереробної галузі становитиме від 0,2\% у 2021 р. до 5,0\% у 2027 р.

Ресурсне забезпечення Програми розвитку АПК Житомирської області, млн грн

\begin{tabular}{|l|c|c|c|c|c|c|c|c|}
\hline \multicolumn{1}{|c|}{ Джерело } & $\mathbf{2 0 2 1}$ р. & $\mathbf{2 0 2 2}$ p. & $\mathbf{2 0 2 3}$ р. & $\mathbf{2 0 2 4}$ p. & $\mathbf{2 0 2 5}$ p. & $\mathbf{2 0 2 6}$ р. & $\mathbf{2 0 2 7}$ р. & Всього \\
\hline Всього ресурсів, & 1772,75 & 1842,95 & 2022,79 & 2162,89 & 2296,11 & 2350,94 & 2507,04 & 14955,47 \\
\hline $\begin{array}{l}\text { у т.ч. } \\
\text { держбюджет }\end{array}$ & 224,90 & 240,60 & 252,60 & 270,70 & 283,40 & 292,30 & 301,80 & 1866,30 \\
\hline обласний бюджет & 13,150 & 14,850 & 16,090 & 17,790 & 18,910 & 19,340 & 20,340 & 120,47 \\
\hline бюджети ОТГ & 2,000 & 2,500 & 3,000 & 3,400 & 3,700 & 4,000 & 4,200 & 22,800 \\
\hline небюджетні кошти & 1532,7 & 1585,0 & 1751,1 & 1871,0 & 1990,1 & 2035,3 & 2180,7 & 12945,90 \\
\hline $\begin{array}{l}\text { Частина бюджетних } \\
\text { коштів у фрінансу- } \\
\text { ванні, \% }\end{array}$ & 13,5 & 14,0 & 13,4 & 13,5 & 13,3 & 13,4 & 13,0 & 13,4 \\
\hline
\end{tabular}

Джерело: побудовано автором на основі [28]

Таблиця 8

Очікувані показники зростання зерновиробництва

згідно Програми розвитку АПК Житомирської області

\begin{tabular}{|c|c|c|c|c|c|c|c|c|c|c|}
\hline Показник & $\begin{array}{l}\text { Од. } \\
\text { виміру }\end{array}$ & $\begin{array}{c}\text { Вихідні } \\
\text { дані }\end{array}$ & 2021 & 2022 & 2023 & 2024 & 2025 & 2026 & 2027 & $\begin{array}{l}\text { Всього } \\
\text { витрат }\end{array}$ \\
\hline $\begin{array}{l}\text { Темп зростання } \\
\text { виробництва ВП } \\
\text { с.-г. }\end{array}$ & $\begin{array}{c}\% \text { до } \\
\text { поперед. } \\
\text { року }\end{array}$ & $98,0^{*}$ & 2,0 & 2,1 & 2,3 & 2,5 & 2,6 & 2,7 & 2,8 & $x$ \\
\hline $\begin{array}{l}\text { Темп зростання } \\
\text { виробництва } \\
\text { продукції } \\
\text { рослинництва }\end{array}$ & $\begin{array}{c}\text { \% до } \\
\text { поперед. } \\
\text { року }\end{array}$ & $97,8^{*}$ & 2,4 & 2,5 & 2,6 & 2,7 & 2,9 & 3,0 & 3,1 & 9535,2 \\
\hline $\begin{array}{l}\text { Обсяг виробництва } \\
\text { зерна }\end{array}$ & тис. Т & $2465^{\star}$ & 2580 & 2600 & 2750 & 2900 & 3100 & 3200 & 3300 & 7301,0 \\
\hline у т.ч. жита & тис. Т & $65,4^{*}$ & 70 & 75 & 78 & 82 & 85 & 88 & 90 & 825,7 \\
\hline гречки & тис. $\mathrm{T}$ & $14,9 *$ & 16 & 18 & 20 & 22 & 23 & 24 & 25 & 363,1 \\
\hline \multicolumn{10}{|c|}{$\begin{array}{l}\text { Питома вага витрат на розвиток зернової галузі у загальних витратах на реалізацію } \\
\text { програми, \% }\end{array}$} & 76,6 \\
\hline
\end{tabular}

* - фрактичні показники 2020 р. 
У хлібопекарській промисловості теж очікується зростання - від 0,1\% у 2023 р. до 0,5\% в рік до 2027 р. Загальний обсяг витрат на реалізацію запланованих показників становить 495,0 та 98,4 млн грн у зернопереробній та хлібопекарській галузі відповідно. Питома вага витрат на розвиток харчової промисловості регіону у загальному обсязі фрінансування Програми складає 22,3\%. Зазначене сприятиме поліпшенню соціально-економічної ефективності зерновиробництва в Житомирській області, що втілюється у збільшенні зернозабезпечення 1 особи населення області в рік 32050 кг у 2020 р. до 2678 кг у 2027 р., або на $30,6 \%$. Також розвиток сприятиме зростанню зайнятості населення. Передбачається створення 550 нових робочих місць в області.

Основні напрями зростання ефрективності зерновиробництва регіону мають бути спрямовані на створення сприятливих умов для аграрного бізнесу, а також підтримки особистих селянських господарств (рис. 3).

Для нішевих культур Житомирської області мають бути запроваджені різні напрями дер- жавної підтримки, зокрема дотації у збільшення посівних площ і урожайності гречки та жита.

Впровадження досягнень технічного прогресу у аграрний сектор сприятиме підвищенню продуктивності праці та продуктивності самих зернових культур. Це автопілотовані комбайни, дрони-обрискувачі, автономні метеостанції тощо. Так, наприклад, впровадження GPS-трекінгу техніки дозволяє в режимі реального часу відстежувати й автоматизувати їі переміщення та контролювати витрати палива. Використовують такі технічні досягнення наступні підприємства області: ТОВ «Агрорегіон», ТОВ «ВП «Полісся», ТОВ «Сігнет Цетр», ТОВ «Аграрний фронд Терещенка», СТОВ «Птахівник», ПП «Галекс Агро» [29]. Окрім того $€$ й інші значні досягнення у сорері виробництва і переробки сільськогосподарської продукції. Зокрема, у 2020 р. створено регіональний інноваційнокосмічний кластер на базі музею космонавтики ім. С. П. Корольова, де реалізують пілотні проєкти; на території Житомирського району побудовано найсучасніший в Україні

Зернове господарство та зернопереробка

- обсяг фінансування - 8508,8 млн грн

\section{Перелік заходів}

- оновлення зернозбирального парку

- розширення інфраструктури для зберігання зерна (будівництво елеваторів та сушки зерна)

- удосконалення структури та впровадження досягнень селекції і насінництва,

- застосування біотехнологій у виробництві

- модернізація виробничих потужностей борошномельних підприємств

- розширення асортиментного переліку хліба та хлібобулочних виробів

- встановлення пакувального обладнання на хлібопекарських підприємствах

\section{Очікувані результати}

- збільшення обсягів виробництва продовольчого зерна (гречки і жита)

- покращення матеріально-технічної бази

- створення елітних насінницьких господарств

- забезпечення с.-г. підприємств високоякісним посівним матеріалом

- зміцнення продовольчої безпеки населення регіону

- створення нових робочих місць

- покращення якості та безпечності хлібобулочних виробів

Рис. 3. Організаційно-економічні заходи зростання зерновиробництва в Житомирській області 
насіннєвий завод міжнародної компанії Bayer з виробництва і доробки насіння кукурудзи та ріпаку DEKALB, обладнаний сучасною технікою A\&K Power Husker i Cimbria, найвищим рівнем комп'ютеризації та автоматизації всіх виробничих процесів.

\section{Висновки.}

1. Галузь зерновиробництва у Житомирській області має переважно інтенсивних тип розвитку. Зокрема, спостерігається збільшення валових зборів зерна на $27,8 \%$ за рахунок зростання урожайності на 17,2\%, 3 одночасним зниження посівних площ на $14 \%$.

2. Негативним економічним процесом $\epsilon$ щорічне зростання виробничої собівартість зернової продукції до 348,3 грн/ц у 2020 р., що вище, ніж у 2015 р. у два рази або на 169 грн/ц. Найвища собівартість гречки 1139,7 грн/ц, найнижча - кукурудзи на зерно 329,1 грн/ц. У розрахунку на 1 га посівної площі собівартість становить 20 тис грн. У структурі собівартості найбільші питомі витрати становлять витрати на мінеральні добрива - 17,1\% та насіння - 10,9\%.

3. Рентабельність виробництва зернових в Україні і Житомирській області у 2021 р. становить 23,8 та 20,2\% відповідно. В Україні у розрізі зернових культур найвищий рівень рентабельності виробництва гречки - 44,9\% та кукурудзи на зерно - 29,1\%.

4. На ефрективність виробництва суттєво впливають наступні чинники. Технологічні - родючість ґрунтів, технологія обробітку ґрунту, норма висіву та внесення мінеральних добрив, строки збору урожаю, технічне забезпечення тощо. До економічних належать - структура виробництва, ринкова кон'юнктура, урожайність, собівартість та структура витрат виробництва, ціна реалізації.

5. Згідно державної програми розвитку АПК у Житомирській області передбачається срінансування галузі у розмірі 7301,0 млн грн, що дозволить підвищити обсяги виробництва зерна до 3,3 млн т або на 33\%, темп зростання зернопереробки становитиме 105\%, хлібопекарської промисловості - 100,5\%, виробництво зернових на 1 особу становитиме 2,7 т.

6. Головними організаційно-економічними напрями підвищення ефективності зерновиробництва вбачаються: у галузі зерновиробництва - оновлення зернозбирального парку, розширення інсрраструктури для зберігання зерна, впровадження досягнень селекції і насінництва, застосування біотехнологій; у галузі зернопереробки - модернізація виробничих потужностей борошномельних підприємств, встановлення пакувального обладнання на хлібопекарських, розширення товарного асортименту.

7. Очікуваними результатами є: збільшення обсягів виробництва продовольчого зерна (гречки і жита), покращення матеріально-технічної бази, створення елітних насінницьких господарств, забезпечення с.-г. підприємств високоякісним посівним матеріалом, продовольча безпека населення регіону, створення нових робочих місць, покращення якості та безпечності хлібобулочних виробів. Основними культурами, в які направлятимуться держані дотації $є$ гречка і жито.

Перспективами подальших досліджень $€$ оптимізація посівних площ з врахуванням прибутковості культур.

\section{СПИСОК ВИКОРИСТАНИХ ДЖЕРЕЛ:}

1. Андрійчук В.Г. Ефеективність діяльності аграрних підприємств: теорія, методика, аналіз : монограсрія. Київ : КНЕУ, 2005. 206 с.

2. Саблук П.Т. Агропромисловий комплекс України: стан, тенденції та перспективи розвитку. Інфрормаційно-аналітичний збірник. Випуск 4. Київ : IAE, 2000.

3. Нелеп В.М. Тенденції розвитку сільського господарства в Україні та світі. Економіка АПК. 2015. № 7. C. 100-105. URL: http://nbuv.gov.ua/UJRN/E_apk_2015_7_15

4. Черевко Г.В., Гарасим П.М., Колодійчук В.А., Козак Т.Р. Економіка зернопродуктового комплексу АПК. Львів : Українські технології, 2000.

5. Череп А.В., Стрілець Є.М. Ефрективність як економічна категорія. Ефективна економіка. 2013. № 1. URL: http://www.economy.nayka.com.ua/?op=1\&z=1727

6. Погребняк А.Ю., Лінник І.М. Методичні підходи щодо оцінки есрективності діяльності підприємства. Сучасні проблеми економіки і підприємнищтво. 2017. № 19. С. 187-192.

7. Драгоєва О.В., Морозович А.В. Методи оцінки економічної ефективності виробництва сільськогосподарської продукції. Вісник СНТ НHI бізнесу і менеджменту ХНТУСГ. 2020. № 1. С. 102-105. URL: http://dspace.khntusg.com.ua/bitstream/123456789/11875/1/33.pdf

8. Зигрій О.В. Методичні підходи дооцінки економічної ефективності підприємств переробної промисловості. URL: https://bit.ly/3nlhE3t 
9. Жук В.М., Сичевський М.П. Розвиток зернового ринку. Облік і фрінанси АПК: освітній портал. URL: http://magazine.faaf.org.ua/rozvitok-zernovogo-rinku-1275.html

10. Обсяг виробництва, урожайність та зібрана площа сільськогосподарських культур за їх видами на 01 вересня 2021 року. Державна служба статистики України. URL: http://www.ukrstat.gov.ua/

11.Виробництво сільськогосподарських культур. Головне управління статистики у Житомирській області. URL: http://www.zt.ukrstat.gov.ua/StatInfo/Sil/valova.htm

12. Виробництво сільськогосподарських культур за категоріями господарств на 1 жовтня 2021 р. Головне управління статистики у Житомирській області. URL: http://www.zt.ukrstat.gov.ua/StatInfo/Sil/valova.htm

13. Витрати підприємств на виробництво продукції сільського господарства у 2020 р. Статистичний збірник. Державна служба статистики України. URL: http://www.ukrstat.gov.ua/

14. Собівартість вирощування пшениці зросла, а ціни на зерно знизилися. SuperAgronom.com. URL: https://superagronom.com/news/7705-sobivartist-viroschuvannya-pshenitsi-zrosla-a-tsini-na-zerno-znizilisya

15. Потаєва O. AgroTimes. 2021. URL: https://agrotimes.ua/agromarket/u-2021-roczi-rentabelnistvyroshhuvannya-pshenyczi-dohodytyme-do-90-fahova-dumka/

16. Рибка, В., Компанієць, В., Кулик, А. Виробництво зерна у розрізі витрат. Агробізнес сьогодні. 2018. URL: http://agro-business.com.ua/agro/ahronomiia-sohodni/item/10111-vyrobnytstvo-zerna-u-rozrizi-vytrat.html

17. Кодекс кращих сільськогосподарських практик. URL: https://mepr.gov.uafilesdocs

18. Внесення мінеральних добрив від урожай сільськогосподарських культур 2020 року. Головне управління статистики у Житомирській області. URL: http://www.zt.ukrstat.gov.ua/StatInfo/Sil/valova.htm

19. Седіло, Г.М., Коник, Г.С., Шувар, А.М. Рекомендації з особливостей технології вирощування озимих зернових під урожай 2019 р. Оброшино: Інститут сільського господарства Карпатського регіону НААН. 2018. URL: https://isgkr.com.ua/images/sampledata/recomendaciy/recomdaciy2018.pdf

20. Застосування пестицидів під урожай сільськогосподарських культур 2020 року. Державна служба статистики України. URL: http://www.zt.ukrstat.gov.ua/StatInfo/Sil/valova.htm

21. Про інститут сільського господарства Західного Полісся. Інститут сільського господарства Західного полісся НАAН України. URL: http://www.isg.rv.ua/index.php/institut/pro-istitut/1-pro-institut-silskogo-gospodarstvazakhidnogo-polissya

22. Сортовые предпочтения украинских аграриев при выборе посевного материала озимой пшеницы. АПК Инфрорм. 2018. URL: https://www.apk-inform.com/ru/apk_itogi/1093510

23. Голик Л., Заїка $€$., Ковальчук С., Клименко І. Поліська-90: 20 років успіху. URL: https://a7d.com.ua/ plants/22198-polska-90-20-rokv-usphu.html

24. Виробництво зерна у розрізі витрат. Агробізнес сьогодні. 2018. URL: http://agro-business.com.ua/agro/ ahronomiia-sohodni/item/10111-vyrobnytstvo-zerna-u-rozrizi-vytrat.html

25. Середні ціни продукції сільського господарства, реалізованої підприємствами за регіонами. Державна служба статистики України. URL: http://www.zt.ukrstat.gov.ua/StatInfo

26. Товарна структура зовнішньої торгівлі Житомирської області у січні-серпні 2021 р. Головне управління статистики у Житомирській області. URL: http://www.zt.ukrstat.gov.ua/Statlnfo/Zt/zovn_r6.htm

27. Іваненко Т.Я., Порудєєва Т.В. Оцінка розвитку зернового ринку Причорноморського регіону України. Причорноморські економічні студії. 2020. № 59-2. C. 71-76. URL: http://bses.in.ua/journals/2020/59_2_2020/13.pdf

28. Програма розвитку агропромислового комплексу Житомирської області на 2021-2027 рр. URL: https://economy-zt.gov.ua/files/AGR/2021/Program21-27/Program_devel_APR_2021-2027.pdf

29. Агропромисловий комплекс, промисловість та інвестиції: досягнення Житомирської області за 30 років Незалежності України 16.08.2021. URL: https://bit.ly/3wjyqm0

\section{REFERENCES:}

1. Andriichuk, V.H. (2005) Efektyvnist diialnosti ahrarnykh pidpryiemstv: teoriia, metodyka, analiz [The efficiency of agricultural enterprises: theory, methodology, analysis]. Kyiv: KNEU. (in Ukrainian)

2. Sabluk, P.T. (2000) Ahropromyslovyi kompleks Ukrainy: stan, tendentsii ta perspektyvy rozvytku [Agroindustrial complex of Ukraine: state, tendencies and prospects of development]. Informatsiino-analitychnyi zbirnykInformation-analytical collection. Kyiv: IAE, vol. 4. (in Ukrainian)

3. Nelep, V.M. (2015) Tendentsii rozvytku silskoho hospodarstva v Ukraini ta sviti [Trends in agricultural development in Ukraine and the world]. Ekonomika APK - Economics of agro-industrial complex, 7, 100-105. Retrieved from: http://nbuv.gov.ua/UJRN/E_apk_2015_7_15 (in Ukrainian)

4. Cherevko, H.V., Harasym, P.M., Kolodiichuk, V.A. \& Kozak, T.R. (2000) Ekonomika zernoproduktovoho kompleksu APK [Economics of the grain complex of agro-industrial complex]. Lviv: Ukrainian technologies. (in Ukrainian) 
5. Cherep, A.V. \& Strilets, Ye.M. (2013) Efektyvnist yak ekonomichna katehoriia [Efficiency as an economic category]. Efektyvna ekonomika - Efficient economy, 1. Retrieved from: http://www.economy.nayka.com.ual ?op $=1 \& z=1727$. (in Ukrainian)

6. Pohrebniak, A.Yu. \& Linnyk, I.M. (2017) Metodychni pidkhody shchodo otsinky efektyvnosti diialnosti pidpryiemstva. [Methodical approaches to assessing the effectiveness of the enterprise]. Suchasni problemy ekonomiky i pidpryiemnytstvo - Modern problems of economy and entrepreneurship, 19, 187-192. (in Ukrainian)

7. Drahoieva, O.V. \& Morozovych, A.V. (2020) Metody otsinky ekonomichnoi efektyvnosti vyrobnytstva silskohospodarskoi produktsii [Methods for assessing the economic efficiency of agricultural production]. Visnyk SNT NNI biznesu i menedzhmentu KhNTUSH - SNT Bulletin of the Institute of Business and Management of KhNTUSG, 1, 102-105. Retrieved from: http://dspace.khntusg.com.ua/bitstream/123456789/11875/1/33.pdf (in Ukrainian)

8. Zyhrii, O.V. Metodychni pidkhody dootsinky ekonomichnoi efektyvnosti pidpryiemstv pererobnoi promyslovosti [Methodical approaches to the assessment of economic efficiency of manufacturing enterprises]. Retrieved from: https://bit.ly/3nlhE3t (in Ukrainian)

9. Zhuk, V.M. \& Sychevskyi, M.P. (2011) Rozvytok zernovoho rynku [Grain market development]. Oblik i finansy APK: osvitnii portal - Accounting and finance of agro-industrial complex: educational portal. Kyiv: Agrarian Science, 92-101. Retrieved from: http://magazine.faaf.org.ua/rozvitok-zernovogo-rinku-1275.html (in Ukrainian)

10. Obsiah vyrobnytstva, urozhainist ta zibrana ploshcha silskohospodarskykh kultur za yikh vydamy na 01 veresnia 2021 roku [Production volume, yield and harvested area of agricultural crops by their types as of September 1, 2021]. Derzhavna sluzhba statystyky Ukrainy - State Statistics Service of Ukraine. Retrieved from: http://www.ukrstat.gov.ua/ (in Ukrainian)

11. Vyrobnytstvo silskohospodarskykh kultur [Crop production]. Holovne upravlinnia statystyky u Zhytomyrskii oblasti - Main Department of Statistics in Zhytomyr Oblast. Retrieved from: http://www.zt.ukrstat.gov.ua/StatInfo/Sil/ valova.htm (in Ukrainian)

12. Vyrobnytstvo silskohospodarskykh kultur za katehoriiamy hospodarstv na 1 zhovtnia 2021 r. [Production of agricultural crops by categories of farms on October 1, 2021]. Holovne upravlinnia statystyky u Zhytomyrskii oblasti Main Department of Statistics in Zhytomyr Oblast. Retrieved from: http://www.zt.ukrstat.gov.ua/Statınfo/Sil/valova.htm (in Ukrainian)

13. Vytraty pidpryiemstv na vyrobnytstvo produktsii silskoho hospodarstva u $2020 \mathrm{r}$. [Expenditures of enterprises on agricultural production in 2020]. Statystychnyi zbirnyk. Derzhavna sluzhba statystyky Ukrainy - Statistical collection. State Statistics Service of Ukraine. Retrieved from: http://www.ukrstat.gov.ua/ (in Ukrainian)

14. Sobivartist vyroshchuvannia pshenytsi zrosla, a tsiny na zerno znyzylysia [The cost of growing wheat has risen, and grain prices have fallen]. SuperAgronom.com. Retrieved from: https://superagronom.com/news/7705sobivartist-viroschuvannya-pshenitsi-zrosla-a-tsini-na-zerno-znizilisya (in Ukrainian)

15. Potaieva, O. (2021) U 2021 rotsi rentabelnist vyroshchuvannia pshenytsi dokhodytyme do 90\% [In 2021, the profitability of growing wheat will reach 90\%]. AgroTimes. Retrieved from: https://agrotimes.ua/agromarket/u-2021-roczi-rentabelnist-vyroshhuvannya-pshenyczi-dohodytyme-do-90-fahova-dumka/ (in Ukrainian)

16. Rybka, V., Kompaniiets, V., Kulyk, A. (2018) Vyrobnytstvo zerna u rozrizi vytrat. Vyrobnytstvo zerna u rozrizi vytrat [Grain production in terms of costs]. Ahrobiznes sohodni - Agribusiness today. Retrieved from: http://agro-business.com.ua/agro/ahronomiia-sohodni/item/10111-vyrobnytstvo-zerna-u-rozrizi-vytrat.html (in Ukrainian)

17. Kodeks krashchykh silskohospodarskykh praktyk. Code of best agricultural practices. Retrieved from: https://mepr.gov.uafilesdocs (in Ukrainian)

18. Vnesennia mineralnykh dobryv vid urozhai silskohospodarskykh kultur 2020 roku. [Application of mineral fertilizers from the harvest of agricultural crops in 2020]. Holovne upravlinnia statystyky u Zhytomyrskii oblasti - Main Department of Statistics in Zhytomyr Region. Retrieved from: http://www.zt.ukrstat.gov.ua/StatInfo/Sil/valova.htm (in Ukrainian)

19. Sedilo, H.M., Konyk, H.S., Shuvar, A.M. (2018) Rekomendatsii z osoblyvostei tekhnolohii vyroshchuvannia ozymykh zernovykh pid urozhai $2019 \mathrm{r}$. [Recommendations on the features of the technology of growing winter cereals for the 2019 harvest]. Obroshino: Institute of Agriculture of the Carpathian Region NAAS. Retrieved from: https://isgkr.com.ua/images/sampledata/recomendaciy/recomdaciy2018.pdf (in Ukrainian)

20. Zastosuvannia pestytsydiv pid urozhai silskohospodarskykh kultur 2020 roku [Application of pesticides for the 2020 crop harvest]. Derzhavna sluzhba statystyky Ukrainy - State Statistics Service of Ukraine. Retrieved from: http://www.zt.ukrstat.gov.ua/StatInfo/Sil/valova.htm (in Ukrainian)

21. Pro instytut silskoho hospodarstva Zakhidnoho Polissia [About the Institute of Agriculture of Western Polissya]. Instytut silskoho hospodarstva Zakhidnoho polissia NAAN Ukrainy - Institute of Agriculture of the Western Polissya NAAS of Ukraine. Retrieved from: http://www.isg.rv.ua/index.php/institut/pro-istitut/1-pro-institut-silskogo-gospodarstva-zakhidnogo-polissya (in Ukrainian) 
22. Sortovye predpochtenyia ukraynskykh ahraryev pry vybore posevnoho materyala ozymoi pshenytsy (2018) [Varietal preferences of Ukrainian farmers when choosing a seed for winter wheat]. APK Inform. Retrieved from: https://www.apk-inform.com/ru/apk_itogi/1093510 (in Russian)

23. Holyk, L., Zaika, Ye., Kovalchuk, S. \& Klymenko, I. Poliska-90: 20 rokiv uspikhu [Polissya-90: 20 years of success]. Retrieved from: https://a7d.com.ua/plants/22198-polska-90-20-rokv-usphu.html (in Ukrainian)

24. Vyrobnytstvo zerna u rozrizi vytrat [Grain production in terms of costs]. Ahrobiznes sohodni-Agribusiness today. Retrieved from: http://agro-business.com.ua/agro/ahronomiia-sohodni/item/10111-vyrobnytstvo-zerna-u-rozrizi-vytrat.html (in Ukrainian)

25. Seredni tsiny produktsii silskoho hospodarstva, realizovanoi pidpryiemstvamy za rehionamy [Average prices of agricultural products sold by enterprises by region]. Derzhavna sluzhba statystyky Ukrainy - State Statistics Service of Ukraine. Retrieved from: http://www.zt.ukrstat.gov.ua/StatInfo (in Ukrainian)

26. Tovarna struktura zovnishnoi torhivli Zhytomyrskoi oblasti u sichni-serpni 2021 r. [Commodity structure of foreign trade of Zhytomyr region in January-August 2021]. Holovne upravlinnia statystyky u Zhytomyrskii oblasti - Main Department of Statistics in Zhytomyr Region. Retrieved from: http://www.zt.ukrstat.gov.ua/StatInfo/Zt/zovn_r6.htm (in Ukrainian)

27. Ivanenko, T.Ya. \& Porudieieva, T.V. (2020) Otsinka rozvytku zernovoho rynku Prychornomorskoho rehionu Ukrainy [Assessment of the development of the grain market of the Black Sea region of Ukraine]. Prychornomorski ekonomichni studii - Black Sea Economic Studies, 59-2, 71-76. Retrieved from: http://bses.in.ual journals/2020/59_2_2020/13.pdf (in Ukrainian)

28. Prohrama rozvytku ahropromyslovoho kompleksu Zhytomyrskoi oblasti na 2021-2027 rr. [The program of development of the agro-industrial complex of the Zhytomyr region for 2021-2027]. Retrieved from: https://economy-zt.gov.ua/files/AGR/2021/Program21-27/Program_devel_APR_2021-2027.pdf (in Ukrainian)

29. Ahropromyslovyi kompleks, promyslovist ta investytsii: dosiahnennia Zhytomyrskoi oblasti za 30 rokiv Nezalezhnosti Ukrainy. 16.08.2021. Agro-industrial complex, industry and investments: achievements of Zhytomyr region for 30 years of Independence of Ukraine. Retrieved from: https://bit.ly/3wjyqm0 (in Ukrainian) 